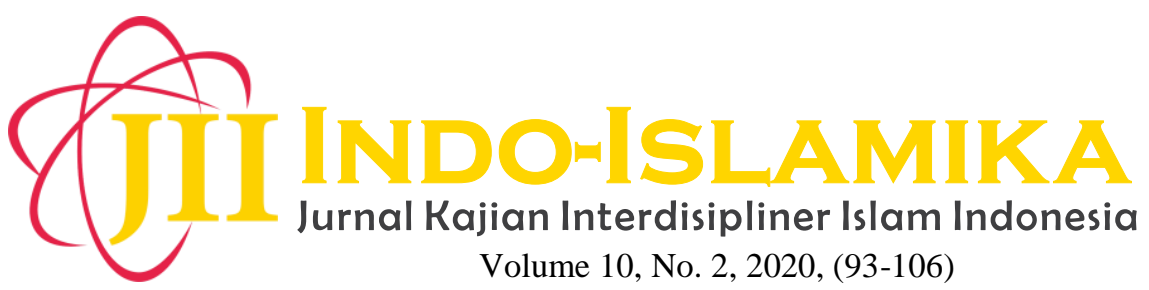

Sekretariat : Graduate School Syarif Hidayatullah State Islamic University (UIN) Jakarta

Website OJS : http://journal.uinjkt.ac.id/index.php/indo-islamika/index

E-mail : indoislamika@uinjkt.ac.id

\title{
Peran Guru Ngaji di Era Sustainable Development Goals (SDGs) (Studi Kasus di Desa Semat Tahunan Jepara)
}

\author{
Ahmad Saefudin, Nur Fitriyah \\ Universitas Islam Nahdlatul Ulama Jepara, Indonesia \\ Corresponding E-mail: ahmadsaefudin@unisnu.ac.id
}

\begin{abstract}
The phenomenon of globalization has entered people's lives, including in Semat Village, Tahunan District, Jepara Regency. The indicator is the development of information technology tools and changes in people's attitudes and lifestyles that tend to follow modern styles. Even though, globalization has not discouraged people from participating in several activities that are in line with the SDGs target in the economic and education sectors, especially in efforts to end poverty and ensure inclusively and quality education. This study aims to emphasize the role of guru ngaji in promoting sustainable global development (SDGs) in the economic and educational domains. A crucial research question that will be answered is whether it is true that global phenomena can cause the younger generation to become increasingly dependent on technological tools and the gradual fading of the sense of solidarity among fellow communities.
\end{abstract}

Keywords: Religious teachers, Globalization era, SDGs

\begin{abstract}
Abstrak
Fenomena globalisasi telah merasuki kehidupan masyarakat, termasuk di Desa Semat, Kecamatan Tahunan, Kabupaten Jepara. Indikatornya adalah perkembangan perangkat teknologi informasi dan perubahan sikap dan gaya hidup masyarakat yang cenderung mengikuti gaya modern. Padahal, globalisasi tidak menyurutkan semangat masyarakat untuk mengikuti berbagai kegiatan yang sejalan dengan target SDGs di bidang ekonomi dan pendidikan, terutama dalam upaya pengentasan kemiskinan dan menjamin pendidikan yang inklusif dan berkualitas. Penelitian ini bertujuan untuk menekankan peran guru ngaji dalam mendorong pembangunan global berkelanjutan (SDGs) dalam domain ekonomi dan pendidikan. Pertanyaan penelitian krusial yang akan dijawab adalah apakah benar fenomena global dapat menyebabkan generasi muda semakin bergantung pada perangkat teknologi dan perlahan memudarnya rasa solidaritas antar sesama komunitas.
\end{abstract}

Kata Kunci: Guru ngaji, Globalization era, SDGs

\section{PENDAHULUAN}

Terminologi guru ngaji, yang dalam istilah agama kerap disebut ustaz, mudarris, mu'alim, dan mu'addib, pada dasarnya merupakan sebutan untuk orang yang mengajarkan ilmu keislaman kepada masyarakat. Julukan lain yang lebih familiar di telinga masyarakat Indonesia ialah guru, dosen, tutor, dan kiai. Sementara dalam Bahasa Inggris, dijumpai beberapa kata yang berdekatan artinya dengan guru ngaji, yaitu 
teacher (guru atau pengajar) dan tutor (guru pribadi atau guru yang mengajar di rumah). ${ }^{1}$ Dalam konteks penelitian ini, yang dimaksud dengan term guru ngaji ialah seseorang yang mengajarkan ilmu agama secara luas kepada masyarakat supaya memiliki akhlak yang terpuji, di samping memiliki kapasitas pengetahuan agama yang luas. Gelar guru ngaji umumnya disematkan oleh masyarakat kepada pemuka agama Islam karena dianggap sebagai figur intelektual yang nasihatnya dianut khalayak luas. Perspektif regulasi Sistem Pendidikan Nasional, guru ngaji bergerak dalam sektor pendidikan non-formal. ${ }^{2}$ Pada ruang lingkup yang lebih spsesifik, guru ngaji dalam studi ini mengarah kepada seorang ustaz yang mengajarkan Alquran di Desa Semat Kabupaten Jepara yang sangat disegani oleh masyarakat karena sikap ramah, sabar, dan keihlasannya dalam mendidik anak-anak kampung.

Di tengah fenomena globalisasi dengan segala dampak turunannya, predikat guru ngaji bagi sebagian besar masyarakat rural tetap prestise dan tidak diberikan kepada sembarang orang. Keluasan ilmu keagamaan saja tak cukup. Syarat lain yang cukup fundamental agar seseorang dijuluki guru ngaji ialah aspek kebersahajaan dan semangat pengabdian. Hal ini seperti ungkapan informan penelitian yang bernama Ustaz Sholihun, guru ngaji di Desa Semat, Tahunan, Jepara, pada kesempatan wawancara dengan peneliti berikut ini:

Menjadi guru ngaji sangatlah tidak mudah, karena itu pekerjaan yang lillahi ta'ala tidak mengharap apapun kecuali mendapatkan ridha-Nya dan harus ikhlas tanpa pamrih dalam memberikan ilmu yang dimiliki. ${ }^{3}$

Sikap kesederhanaan tersebut, seperti diungkapkan Muhammad Athiyah alAbrasyi, pakar pendidikan Islam dari Mesir, memang harus melekat pada guru ngaji sebagai kode etik. Sifat lain yang juga pentig yaitu zuhud, pemaaf, kebapakan/keibuan, rendah hati, dan menjauhi tabiat kedengkian. 4 Dari sudut pandang pedagogis, eksistensi guru ngaji di tengah masyarakat kampung adalah mengayomi, mengajarkan, mendidik, membina, dan membimbing generasi muda agar menjadi baik (shaleh) dan mulia (akram). ${ }^{5}$

Sejak era 1990-an, fenomena globalisasi memberikan dampak yang signifikan pada sendi-sendi kehidupan manusia. Batas-batas demografi antar bangsa menyusut disebabkan oleh pesatnya perkembangan alat teknologi informasi yang kian canggih. Pakar sosiologi sering menyebutnya dengan "global village" yang ditandai dengan homogenisasi sumber daya ekonomi, sosial, budaya, politik, dan bahkan intelektual. ${ }^{6}$ Pada ujungnya, identitas kebangsaan yang terlanjur mapan ditantang oleh pelbagai alternatif pilihan fenomena global yang sifatnya relatif. Tidak ada lagi identitas tunggal pada ranah sosial, ekonomi, dan budaya. ${ }^{7}$ Dalam ungkapan lain, globalisasi meniscayakan terbentuknya organisasi dan komunikasi antara masyarakat di seluruh

${ }^{1}$ Muhaimin, Pengembangan Kurikulum Pendidikan Agama Islam Di Sekolah, Madrasah, Dan Perguruan Tinggi (Jakarta: Radja Grafindo Persada, 2005), 44.

${ }^{2}$ Ahmad Izudin Zakki, "Peran Guru Ngaji Dalam Pembinaan Akhlaq Pemuda Di Dusun Pandan Desa Canggu Kecamatan Badas Kabupaten Kediri” (UIN Maulana Malik Ibrahim Malang, 2019), 9, http://etheses.uin-malang.ac.id/14411/1/14110086.pdf.

${ }^{3}$ Wawancara dengan Ustaz Sholihun, Guru Ngaji di Desa Semat, Jepara pada 5 September 2019 di Desa Semat Kecamatan Tahunan Kabupaten Jepara.

${ }^{4}$ Ahmad Tafsir, Ilmu Pendidikan Dalam Perspektif Islam (Bandung: Remaja Rosdakarya, 2005), 82.

${ }^{5}$ Khoiriyah, Sosiologi Pendidikan Islam (Yogyakarta: Teras, 2012), 142.

6 Ahmad Fauzi Abdul Hamid, "Globalization of Islamic Education in Southeast Asia," in Southeast Asian Muslims in the Era of Globalization (London: Palgrave Macmillan, 2015), 12, https://doi.org/10.1007/s10531-009-9756-6.

7 John Wiley and Sons, "The New Blackwell Companion to Social Theory," in Handbook of Research Methods in Health Social Sciences, ed. Bryan S. Turner, 2016, 322, https://doi.org/10.1007/978-981-10-5251-4_57. 
dunia untuk mengikuti sistem dan kaidah yang seragam. ${ }^{8}$ Pespektif pembangunan global, dunia internasional kemudian menyepakati klausul Sustainable Development Goals (SDGs) sebagai kelanjutan dari program Millennium Development Goals (MDGs) yang berakhir pada tahun 2015. ${ }^{9}$ Agenda SDGs merupakan kesadaran bersama antar bangsa, tak terkecuali di Indonesia, untuk memecahkan masalah global, seperti: kesenjangan ekonomi yang berujung pada kemiskinan, pemerataan pendidikan, peningkatan kesehatan ibu dan anak, upaya pelestarian lingkungan, dan lain sebagainya. ${ }^{10}$ Riset tentang peran guru $n g a j i$, pada konteks SDGs, layak mendapatkan perhatian dari para peneliti. Seperti yang terjadi di Desa Semat Kecamatan Tahunan Kabupaten Jepara.

Faktanya, peran guru ngaji di kawasan tersebut belum tergantikan, termasuk oleh kecanggihan alat teknologi informasi. Bahkan, kiprah mereka dianggap mampu mengisi kegersangan spiritual remaja. Ainun Najib, guru Madrasah Diniyah yang juga menjadi informan penelitian menegaskan:

Guru ngaji di Desa Semat sangatlah berperan penting karena dapat meminimalisir dampak negatif yang ditimbulkan dari masyarakat itu sendiri, misalnya dapat mengurangi anak muda yang suka nongkrong setiap malam di jalan-jalan kampung. Caranya mengajak mereka ikut kegiatan rutinan mengaji Al-quran. ${ }^{11}$

Dari fakta di atas, dapat ditarik sebuah konklusi bahwa fenomena globalisasi menyimpan ancaman sekaligus tantangan. Sebagai ancaman, globalisasi memungkinkan generasi muda sekarang untuk berkomunikasi dan menerima informasi demikian cepat. Jika tidak ada filter, besar kemungkinan mereka akan mengakses konten informasi yang bertentangan dengan ajaran agama. Sebagai tantangan, bangsa Indonesia dapat mengambil hal-hal yang positif dari majunya ilmu pengetahuan dan teknologi. ${ }^{12}$

Peneliti memilih Desa Semat sebagai obyek penelitian karena desa ini termasuk kawasan pesisir yang terkadang kurang memperhatikan masalah pendidikan keagamaan. Namun demikian, masyarakat desa ini juga bida dikategorikan sudah tergolong maju dengan dibuktikan dengan pesatnya penggunaan alat teknologi informasi, khususnya di kalangan kaum muda. Apalagi, ditambah dengan faktor banyaknya warga asing yang berimigrasi ke desa ini serta banyaknya remaja yang menuntut ilmu hingga ke bangku perguruan tinggi. ${ }^{13}$

Globalisasi tidak menyurutkan masyarakat untuk mengikuti beberapa kegiatan keagamaan. Misalnya, masih banyaknya anak-anak yang mengikuti pendidikan pada lembaga Taman Pendidikan Alquran (TPQ), madrasah diniyah, dan mengaji di surau setelah maghrib. Mereka didampingi seorang guru ngaji yang dipandang oleh masyarakat memiliki keahlian dalam bidang keagamaan. Hal ini sejalan dengan target SDGs pada bidang ekonomi dan pendidikan, utamanya dalam upaya mengakhiri

8 Nurhaidah and M. Insya Musa, "Dampak Pengaruh Globalisasi Bagi Kehidupan Bangsa Indonesia,” Jurnal Pesona Dasar 3, 3 (2015): 1-14.

9 Mohamad Handi Khalifah, Mohammad Soleh Nurzaman, and Muhammad Cholil Nafis, "Optimization of BAZNAS Programs on Sustainable Development Goals (SDGs): Analytic Network Process Approach (ANP),” International Journal of Zakat 2, 2 (2017): 71, https://doi.org/10.37706/ijaz.v2i2.26.

10 Roberto Abimanyu Baggio and Rahma Rosaliana Saraswati, "Islam Menjawab Tantangan SDGS Di Indonesia : A Literatur Review,” RISENOLOGI KPM UNJ 3, 2 (2018): 48.

${ }^{11}$ Wawancara dengan Ustaz Ainun najib, Guru Madrasah Diniyah di Desa Semat, Jepara pada 10 Mei 2019 di Desa Semat Kecamatan Tahunan Kabupaten Jepara.

${ }^{12}$ Hasbi Indra, Pendidikan Islam Tantangan Dan Peluang di Era Globalisasi (Yogyakarta: Deepublish, 2016), 9.

${ }^{13}$ Wawancara dengan H. Shofa, Carik Desa Semat pada 14 Juni 2019 di Desa Semat Kecamatan Tahunan Kabupaten Jepara. 
kemiskinan serta memastikan pendidikan yang inklusif dan berkualitas. ${ }^{14}$

Secara akademik, riset ini sangat penting. Disamping memahami konsep globalisasi secara teoretik berikut dampaknya bagi masyarakat desa, studi ini sekaligus ingin membuktikan satu hipotesis; apakah benar bahwa fenomena global dapat mengakibatkan generasi muda semakin ketergantungan dengan alat teknologi, memudarnya sedikit demi sedikit rasa solidaritas antar sesama masyarakat, dan peran penting guru ngaji di desa kian disepelekan dan mengalami distorsi. Kontribusi akademik yang tak kalah penting ialah mendeskripsikan peran guru ngaji dalam mempromosikan pembangunan global berkelanjutan (SDGs) pada domain ekonomi dan pendidikan.

\section{METODE}

Penelitian ini merupakan jenis penelitian studi kasus (case study) dengan pendekatan kualitatif. Seluruh data tentang peran guru ngaji di era globalisasi ditampilkan dalam keadaan sewajarnya atau sebagaimana adanya (natural setting) sebagaimana paparan informan penelitian. ${ }^{15}$ Data primer bersumber dari guru ngaji dan masyarakat Desa Semat (mulai dari anak-anak sampai orang tua yang ada di desa). Lantas, sumber tersebut dikolaborasikan dengan data sekunder berupa buku, artikel jurnal, dokumen, dan arsip lain yang berkaitan dengan teori globalisasi dan peran guru ngaji dalam mengantisipasi dampak negatifnya.

Dalam mengumpulkan data, peneliti mengunakan observasi partisipatif dengan cara berinteraksi langsung dengan subyek penelitian. ${ }^{16}$ Peneliti secara langsung ikut ambil bagian atau melibatkan diri dalam kegiatan belajar mengajar yang dilakukan guru ngaji kepada anak-anak dan juga masyarakat di Desa semat. Peneliti juga melakukan wawancara dengan model tidak terstruktur kepada informan. Pedoman wawancara yang digunakan hanya berupa garis-garis besar permasalahan yang akan ditanyakan. Dalam wawancara tidak terstruktur, peneliti belum mengetahui secara pasti data apa yang akan diperoleh, sehingga peneliti lebih banyak mendengarkan apa yang diceritakan oleh informan. Berdasarkan analisis terhadap setiap jawaban, peneliti dapat mengajukan berbagai pertanyaan berikutnya yang lebih spesifik berkaitan dengan topik penelitian. Dalam hal ini, informan kuncinya adalah guru ngaji, yakni Bapak H. Manfaat dan juga Bapak H. Sholihun, dan beberapa warga Desa Semat. Sebagai pelengkap, peneliti memanfaatkan teknik dokumentasi berupa profil desa, foto kegiatan mengaji, dan arsiparsip sejenis yang berhubungan langsung dengan potret guru ngaji dalam upaya mengantisipasi dampak negatif era global.

Pada tahapan analisis data, peneliti terlebih dahulu mengumpulkan data penelitian dan melakukan penelaahan lebih rinci tentang peran guru ngaji di Desa Semat dalam mempromosikan agenda SDGs. Kemudian merangkumnya, memilih hal-hal yang pokok, memfokuskan pada hal-hal yang penting untuk dicari tema dan polanya. Dengan demikian data yang telah direduksi akan memberikan gambaran yang lebih jelas, dan mempermudah peneliti untuk melakukan pengumpulan data selanjutnya. Data ini selanjutnya disajikan secara kualitatif yaitu dengan menggambarkan hasil informasi yang diperoleh dari informan secara naratif atau berbentuk teks. Penyajian data dilakukan dengan cara data yang diperoleh dari observasi, wawancara dan dokumentasi di lokasi penelitian kemudian dikategorikan menurut permasalahannya dan dibuat dalam bentuk yang sistematis sehingga memudahkan peneliti untuk melihat hubungan antara data satu dengan data yang lain. Harapannya dengan menyajikan data model ini, maka akan memudahkan peneliti dalam menyimpulkan hasil akhir penelitian berupa peran guru ngaji dalam mengantisipasi dampak negatif di era global di Desa Semat.

14 “Tujuan SDG,” 2017, https://www.sdg2030indonesia.org/page/1-tujuan-sdg.

${ }^{15}$ W. Gulo, Metodologi Penelitian (Jakarta: PT Grasindo, 2010), 19.

${ }^{16}$ Sugiyono, Metode Penelitian Kuantitatif, Kualitatif, Dan R\&D (Bandung: Alfabeta, 2014),

230. 


\section{HASIL DAN PEMBAHASAN \\ Eksistensi Guru Ngaji di Era Globalisasi: Sebuah Potret di Desa Semat, Tahunan, Jepara}

Dalam Kamus Besar Bahasa Indonesia, disebutkan bahwa guru ngaji atau ustaz merupakan ahli agama, guru, atau guru besar pada madrasah ataupun lainnya. Guru dan ustaz merupakan suatu kesatuan yang sama-sama ditujukan pada seorang pendidik hanya saja penyebutannya yang berbeda. Guru biasanya digunakan untuk menyebut pendidik yang mengajar di sekolah umum atau formal, sedangkan guru ngaji (ustaz atau ustazah) digunakan untuk sebutan pendidik yang mengajar di lingkungan madrasah, pondok pesantren, dan lingkungan masyarakat yang mengajar pendidikan agama. Ustaz merupakan orang tua pengganti ketika anak didik tidak berada di rumah (di sekolah). ${ }^{17}$

Kualifikasi guru ngaji, pada riset ini sebenarnya identik dengan guru atau pendidik. Mereka adalah figur mudarris yang mengajarkan pelajaran, seorang mu'addib yang mendidik manusia agar lebih beradab, dan juga seorang mu'allim yang bertanggungjawab mengamalkan ilmu yang dimilikinya. Penjelasan tersebut sebagaimana pemaparan Eko Masnoor Efendi selaku Kepala Desa Semat.

Gelar ustaz atau guru ngaji datang dari masyarakat sendiri yang menyamatkan kepada seorang pemuka agama Islam yang dianggapnya sebagai seorang yang berilmu, bisa mengarahkan masyarakat terutama pemuda desa selain itu juga mengamalkan ilmunya kepada orang lain dengan ikhlas hanya mengharap ridha dari Allah SWT yang penting ilmu yang dimilikinya bisa bermanfaat bagi orang lain. ${ }^{18}$

Jadi, dapat disimpulkan bahwa guru ngaji adalah sebutan kepada seseorang dalam masyarakat yang mempunyai ilmu agama lebih tinggi tapi juga bisa mengaplikasikan kepada orang lain terutama pemuda desa. Tidak hanya mengajarkan mengaji saja, tetapi juga memberikan motivasi supaya terhindar dari hal-hal yang bersifat negatif. Seorang ustaz harus mencerminkan sikap sebagai pembawa ajaran agama Islam yang rahmatan lil alamin artinya bisa menjadi rahmat bagi semuanya. Sebutan guru ngaji tidak sesederhana yang dibayangkan. Di dalamnya terkandung makna ilmu, pengajaran, akhlak dan keteladanan. Jadi jangan mudah menyebut atau memberi gelar ustaz atau guru ngaji apabila yang bersangkutan tidak pada porsinya untuk menerima hal tersebut.

Karakteristik guru ngaji perspektif Islam bisa mengacu kepada sosok Lukmanul Hakim yang diceritakan dalam Alquran. Ia selalu bersyukur kepada Allah SWT atas semua nikmat yang diberikan kepadanya, mempunyai sifat rendah hati dan tawadhu', mampu memberikan contoh yang baik kepada santri dengan mengedapankan kepentingan orang lain dibandingkan kepentingan pribadi, mempunyai rasa toleransi yang tinggi kepada orang lain dan bisa menjadi pemicu semangat bagi orang lain. Guru ngaji juga harus memiliki sikap pantang menyerah. ${ }^{19}$

Karakteristik guru ngaji bagi warga Desa Semat ialah mereka yang memiliki keluasan ilmu agama dan mau mengamalkannya kepada orang lain dengan ikhlas tanpa mengharap apapun seperti upah, gaji dan lain-lain. Hal ini tampak dari penjelasan petinggi Desa Semat dalam kesempatan wawancara dengan peneliti berikut ini:

17 Miftahul Ulum, "Pembinaan Kompetensi Ustadz Madrasah Diniyah Melalui Program Tarbiyatul Mu'allimin Di Madrasah Diniyah Takmiliyah Awwaliyah Ar-Rosyidiyah Mambaul Ulum Pangarengan Sampang," MODELING: Jurnal Program Studi PGMI 6, 2 (2019), https://doi.org/10.36835/modeling.v6i2.448.

${ }^{18}$ Wawancara dengan Eko Masnoor Frendi, Petingi Desa Semat pada 16 Oktober 2019 di Desa Semat Kecamatan Tahunan Kabupaten Jepara.

19 Hamka Abdul Aziz, Karakter Guru Profesional Melahirkan Murid Unggul Menjawab Tantangan Masa Depan (Jakarta: Al Mawardi Prima, 2012), 40. 
Seseorang bisa dikatakan sebagai guru ngaji apabila mempunyai pengetahuan agama secara luas, Tidak hanya paham saja dengan apa yang dimiliki, tapi harus bisa mengamalkannya kepada orang lain. Sebenarnya, sebutan ini adalah gelar yang diberikan masyarakat terhadap pemuka agama Islam. ${ }^{20}$

Pendapat ini dikuatkan oleh informan lain yang menjelaskan.

Guru ngaji itu seorang laki-laki yang mengajarkan ilmu agama kepada masyarakat desa Semat. Mulai dari anak-anak hingga orang tua yang tidak pernah membeda-bedakan ketika sedang melakukan kegiatan keagamaan. Selain mengajarkan ilmu agama kepada masyarakat juga menjadi guru di sekolah umum. ${ }^{21}$

Eksistensi guru ngaji di Desa Semat diakhu oleh warga masyarakat desa. Sebagaimana penuturan informan berikut:

Dengan keterbatasan ilmu yang kami miliki sebagai orang tua, guru ngaji di desa sangat membantu kami dalam mengajarkan anak-anak tentang ilmu agama. Karena terkadang anak-anak itu kalau di sinauni orang tuanya suka malas-malasan. Tapi kalau orang lain seperti ustaz, pasti takut dan akhirnya mau untuk belajar agama. Apalagi di sini, ustaz dan ustazahnya itu baik dan sabar. $^{22}$

Guru ngaji memiliki 3 tugas bagi masyarakat yaitu: sebagai pengajar (memberikan pengajaran dengan program yang telah disusun sebelumnya), sebagai pendidik (mengarahkan anak didik menuju kedewasaan yang berkepribadian insan kamil), sebagai pemimpin (bisa mengendalikan diri sendiri, anak didik dan masyarakat yang terkait dengan memberikan contoh yang baik pada orang lain).

Tugas kesehariannya adalah sebagai orang yang memberikan dan mentransfer keilmuannya kepada siswa. Selain itu tugas dan tanggung jawab ustaz diantaranya: mengajar, yaitu suatu usaha mengorganisasikan lingkungan dalam hubungannya dengan santri dan bahan pengajaran yang menimbulkan terjadinya proses belajar, yang kedua adalah membimbing dan mengarahkan anak didiknya agar dapat senantiasa berpikir, bersikap, dan berperilaku positif, dan yang terakhir adalah membina, yaitu berupaya dengan sungguh-sungguh untuk menjadikan sesuatu yang lebih baik dari sebelumnya. ${ }^{23}$

Dari segi kredibilitas, guru ngaji juga mempunyai tangung jawab sosial yang berbeda dengan warga lain pada umumnya. Guru ngaji menjadi panutan terbaik dalam persoalan interaksi sosial.

Di antara tanggung jawab yang dimiliki seorang guru ngaji yaitu menjadi contoh yang baik buat masyarakat desa dengan sifat terpuji yang dimilikinya. Bisa juga memberi nasihat-nasihat dan membimbing masyarakat. ${ }^{24}$

Menjadi guru ngaji bukanlah sesuatu yang mudah, sosoknya yang dijadikan panutan bagi orang lain memiliki tugas dan tanggung jawab yang besar di masyarakat.

Tanggung jawab ustaz adalah membina dan memberikan bimbingan agar memiliki akhlakul karimah, mengamalkan apa yang dimilikinya, dan bisa menjadi makhluk Tuhan (taat kepada ajaran Tuhan) dan makhluk sosial (saling

\footnotetext{
${ }^{20}$ Wawancara dengan Eko Masnoor Frendi, Petingi Desa Semat pada 16 Oktober 2019 di Desa Semat Kecamatan Tahunan Kabupaten Jepara.

21 Wawancara dengan Murtadlo, Modin Desa Semat pada 20 Oktober 2019 di Desa Semat Kecamatan Tahunan Kabupaten Jepara.

22 Wawancara dengan Farida, Warga Desa Semat pada 21 Oktober 2019 di Desa Semat Kecamatan Tahunan Kabupaten Jepara.

23 Aziz, Karakter Guru Profesional Melahirkan Murid Unggul Menjawab Tantangan Masa Depan, 31.

24 Wawancara dengan H. Shofa, Carik Desa Semat pada 2 Desember 2019 di Desa Semat Kecamatan Tahunan Kabupaten Jepara.
} 
menghargai sesama manusia). ${ }^{25}$

Jadi dapat disimpulkan bahwa tanggung jawab seorang ustaz yaitu menjadi tokoh panutan bagi masyarakat karena sangat disegani oleh karena itu ustaz harus memiliki akhlakul karimah, mengamalkan ilmu yang dimilikinya kepada orang lain supaya bermanfaat, mengajarkan orang lain dengan apa yang dimiliki tidak akan membuat kita rugi tapi malah sebaliknya akan membuat hidup kita menjadi berkah, dan yang terakhir adalah memberikan pengarahan pada masyarakat tentang ilmu kegaamaan secara luas, sebisa mungkin mengajak masyarakat untuk selalu berpegang teguh pada ajaran agama Islam.

Selain memiliki karakteristik, tugas, dan tanggung jawab, guru ngaji juga berperan besar dalam upaya membangun moral masyarakat. Walaupun terkadang ada masyarakat yang menyepelekan peran tersebut. Peran ustaz bukan hanya sebagai orang yang ahli ilmu agama saja tapi juga membimbing dan mengajarkan masyarakat tentang ilmu agama. Dalam menyeimbangkan antara pengetahuan agama dan pengetahuan umum sangat penting dengan adanya ustaz yang berperan di masyarakat. Jika dalam suatu lingkungan kurang atau bahkan tidak ada guru ngaji, maka akan terjadi kesenjangan dalam urusan ilmu pengetahuan umum dengan ilmu agama.

Ihwal demikian dirasakan juga oleh Munadi, salah satu warga desa yang menjadi informan penelitian:

Adanya guru ngaji di desa Semat bisa dijadikan sebagai seseorang yang sangat dihormati masyarakat karena sifat terpuji yang dimilikinya, tutur katanya yang sopan, dan tidak bosan dan tidak pamrih dalam mengamalkan ilmu agama yang dimilikinya. ${ }^{26}$

\section{Peran Guru Ngaji pada Era Sustainable Development Goals (SDGs)}

Globalisasi berasal dari kata globe, yang berarti bola bumi. Istilah ini digunakan karena penyebaran informasi yang luar biasa. Dalam waktu sekejap saja melalui fasilitas teknologi komunikasi yang semakin canggih, arus informasi dari satu belahan bumi bisa menyebar secara merata ke seluruh dunia. ${ }^{27}$

Menurut Djamali, dalam perspektif global ada beberapa faktor yang disoroti sebagai fenomena kemunduran umat Islam yaitu kemunduran bidang agama, akhlak, keterbelakangan ilmu pengetahuan dan teknologi, ekonomi, sosial, kesehatan, politik, dan bidang pendidikan. Faktor-faktor tersebut tersebut yang memperlemah peran umat Islam dalam memaksimalkan kemampuan atau daya saing. Oleh karena itu umat Islam harus mampu menyikap dengan arif dan bijaksana sehingga mendapatkan solusi yang benar berdasarkan Al-Qur'an, Hadist, dan Ijtihad para ulama' dan ilmuan di tanah air. ${ }^{28}$

Penjelasan dari Kuntowijoyo di atas sejalan dengan pemikiran Bapak Shofa, Carik Desa Semat berikut ini:

Globalisasi adalah zaman dimana semua kegiatan kita dipermudah dengan adanya teknologi semakin berkembang. Hal tersebut mempermudah akses masyarakat untuk melaksanakan aktivitas sehari-hari. Dengan adanya kemajuan tersebut dapat merubah pola pikir manusia menjadi berkembang. ${ }^{29}$

Suatu desa atau daerah bisa dikatakan sudah terkena arus globalisasi terlihat dari

${ }^{25}$ Ngainum Naim, Menjadi Guru Inspiratif (Yogyakarta: Pustaka Pelajar, 2019), 16.

${ }^{26}$ Wawancara dengan H. Munadi, Warga Desa Semat pada 2 Desember 2019 di Desa Semat Kecamatan Tahunan Kabupaten Jepara.

${ }^{27}$ Kuntowijoyo, Pengantar Ilmu Sejarah (Yogyakarta: Yayasan Bintang Budaya, 1995), 17.

28 Al-Djamali Fadhil, Menerobos Krisis Pendidikan Dunia Islam (Jakarta: PT Golden Terayon Press, 1993), 23.

29 Wawancara dengan H. Shofa, Carik Desa Semat pada 3 Desember 2019 di Desa Semat Kecamatan Tahunan Kabupaten Jepara. 
ciri-ciri yang ada. Diantaranya: adanya kecenderungan masyarakat yang lebih menghargai materialistik, melajarnya budaya permisif (serba boleh) yang mengakibatkan orang melakukan hal-hal baru yang dianggap modern dan meninggalkan adat istiadat yang sudah bertahan lama, dan adanya kecenderungan di masyarakat untuk mengarahkan anaknya agar belajar di lembaga pendidikan yang dapat memenuhi tuntutan hidup duniawi. Sementara lembaga pendidikan yang kurang menjanjikan kebahagiaan hidup duniawi yang kurang diminati. ${ }^{30}$

Fenomena ini dirasakan oleh Nor Ali, salah satu warga Desa Semat. Ia menuturkan:

Di desa kami sudah terkena arus globalisasi dengan adanya ciri-ciri seperti yang terlihat dari berkembangnya alat teknologi, komunikasi dan transportasi misalnya pada mesin mebel semakin waktu semakin berkembang. Alat-alat pertanian yang dahulu menggunakan hewan dalam membajak sawah sekarang sudah menggunakan mesin. Sebagian masyarakat ada yang hanya memerhatikan pendidikan umum dibandingkan pendidikan keagaaman karena baginya dalam sekolah umum sekarang sudah ada pendidikan keagamaan. Budaya Barat juga ditirukan pemuda desa seperti cara berpakaian dan berbicara. ${ }^{31}$

Globalisasi, pada satu kutub tertentu, sebenarnya menguntungkan masyarakat karena semua kegiatan sehari-hari bisa dilakukan dengan mudah. Tuntutan perkembangan zaman globalisasi yang menekankan pada kebebasan, persaingan, pengetahuan melalui perkembangan teknologi dan informasi. Dalam hal ini, globalisasi adalah hasil perubahan dari hubungan masyarakat yang membawa kesadaran baru tentang hubungan atau interaksi antar manusia. ${ }^{32}$

Globalisasi selain menghadirkan peluang positif untuk hidup mewah, nyaman, indah, dan maju juga dapat menghadirkan peluang negatif yaitu menimbulkan keresahan, penyesalan, dan penderitaan. Oleh karena itu penting sekali dalam membentengi diri sendiri dengan pengetahuan yang luas baik umum ataupun keagamaan.

Namun demikian, hanya sedikit orang yang sadar dan secara kritis memahami bahaya globalisasi yang secara sistematik mengancam kehidupan manusia. Sebab globalisasi hanya dipahami dari aspek kemajuan teknologi saja bukan dari aspek-aspek lain yang sebenarnya mengancam kehidupan manusia. ${ }^{33}$ Dampak positif globalisasi bisa dilihat dengan berkembangnya ilmu pengetahuan dan teknologi membuat kehidupan manusia menjadi lebih baik dan berkembangnya perdagangan sampai ke internasional yang bisa meningkatkan kesejahteraan masyarakat suatu Negara. ${ }^{34}$

Pada domain yang lebih spesifik, globalisasi melahirkan konsep pembangunan berkelanjutan atau sering disebut Sustainable Development Goals (SDGs). Prinsip mendasar SDGs adalah menyeimbangkan dimensi ekonomi, sosial, dan lingkungan, meliputi 1) People (manusia), 2) Planet (bumi), 3) Prosperity (kemakmuran), 4) Peace (perdamaian), dan 5) Partnership (kerjasama). ${ }^{35}$ Aspek pendidikan dan kemiskinan

30 Muhtarom H.M., Reproduksi Ulama Di Era Globalisasi: Resistansi Tradisional Islam (Yogyakarta: Pustaka Pelajar, 2005), 80.

31 Wawancara dengan Nor Ali, Warga Desa Semat pada 3 Desember 2019 di Desa Semat Kecamatan Tahunan Kabupaten Jepara.

32 Nurani Soyomukti, Pendidikan Berperspektif Globalisasi (Yogyakarta: Ar-Ruzz Media, 2008), 43.

${ }^{33}$ Musthafa Rembangy, Pendidikan Transfoormatif (Yogyakarta: Teras, 2008), 33.

34 Muhammad Rifq, "Dampak Globalisasi Perdagangan Antara ASEAN-5 Dan China" (Universitas Brawijaya, 2013).

${ }^{35}$ Sekar Panuluh and Meila Riskia Fitri, "Perkembangan Pelaksanaan Sustainable Development Goals (SDGs) Di Indonesia," Biefing Paper 2, (2016): 5, http://www.sdg2030indonesia.org/ancomponent/media/upload-book/Briefing_paper_No_1_SDGS_-2016-Meila_Sekar.pdf. 
masih menjadi pekerjaan rumah Pemerintah Indonesia dalam mencapai target SDGs. ${ }^{36}$ Melalui Peraturan Presiden Republik Indonesia Nomor 59 Tahun 2017 tentang Pelaksanaan Pencapaian Tujuan Pembangunan Berkelanjutan, Pemerintah berusaha keras untuk mengakhiri segala bentuk kemiskinan. Pada tahun 2030, setengah proporsi penduduk Indonesia, baik laki-laki, perempuan, maupun anak-anak, harus lepas dari belenggu kemelaratan. Mereka juga diharapkan memiliki hak yang sama terhadap sumber daya ekonomi dan menjamin perkembangan dan pengasuhan anak usia dini, pengasuhan, pendidikan pra-sekolah dasar yang berkualitas, sehingga mereka siap untuk menempuh pendidikan dasar, pendidikan teknik, kejuruan, pendidikan tinggi, termasuk universitas, yang terjangkau dan berkualitas. ${ }^{37}$

Hasil penelitian lapangan tentang dampak positif globalisasi di Desa Semat di antaranya adalah kemudahan dalam mencari informasi, meningkatnya kualitas SDM, dan memudahkan pemasaran. Rincian dampak positif tersebut akan dijelaskan peneliti sebagai berikut:

1. Kemudahan dalam mencari informasi

Globalisasi memudahkan masyarakat ketika membutuhkan informasi seperti lowongan pekerjaan, keadaan desa lain, peluang usaha di luar daerah.Semuanya berkat kecanggihan alat komunikasi. Dengan internet. Misalnya, orang-orang di berbagai belahan bumi dapat mengakses informasi dengan cepat baik di dalam maupun luar negeri. Akses tersebut dapat tersambung melalui media sosial seperti website, facebook, instagram, twitter, blog, dan lain sebagainya. Seperti yang dipaparkan anggota Karang Taruna Desa Semat tentang memudahkannya informasi "Kita bisa mendapatkan informasi apa saja dengan cepat karena itu dapat mempermudahkan masyarakat desa yang jauh dari kota seperti Desa Semat". ${ }^{38}$

2. Meningkatnya kualitas Sumber Daya Manusia Desa

Globalisasi memunculkan adanya keinginan untuk melakukan perbaikan di segala bidang termasuk pendidikan. Pendidikan dipandang sebagai komponen paling penting yang dapat menghasilkan sumber daya manusia yang berkualitas. Dengan mengembangkan SDM lewat program-program pendidikan diharapkan dapat menghasilkan manusia yang berkualitas tidak hanya cerdas secara intelektual saja tapi juga mempunyai keterampilan dan pribadi yang positif mengenai keanekaragamaan budaya dalam menghadapi era globalisasi. Hal tersebut sesuai dengan yang disampaikan Kepala Desa Semat.

Karena keinginan rasa bersaing yang kuat, membuat masyarakat mempunyai rasa ingin tahu yang besar untuk banyak belajar tentang ilmu pengetahuan. Supaya tidak kalah dengan masyarakat luar. Hal itu bisa meningkatkan kualitas SDM terutama bagi pemuda desa kami, supaya bisa menjadi generasi penerus yang mempunyai pola pikir lebih berkembang. ${ }^{39}$

3. Memudahkan pemasaran

Berkembangnya alat tekonologi bisa menambah banyak teman atau relasi bisnis yang dijalin sampai ke luar kota bahkan luar negeri. Tentu kondisi ini mempunyai keuntungan tersendiri bagi masyarakat pebisnis untuk menambah konsumen ataupun bisa bergabung dengan orang lain.

${ }^{36}$ Ishartono and Santoso Tri Raharjo, "Sustainable Development Goals (SDGs) Dan Pengentasan Kemiskinan,” Share: Social Work Jurnal 6, 2 (2016): 163, https://doi.org/10.5005/jp/books/13071_5.

${ }^{37}$ Presiden Republik Indonesia, "Peraturan Presiden Republik Indonesia Nomor 59 Tahun 2017 Tentang Pelaksanaan Pencapaian Tujuan Pembangunan Berkelanjutan” (2017).

38 Wawancara dengan Khusnun Alif Rohman, Anggota Karang Taruna Desa Semat pada 26 Desember 2019 di Desa Semat Kecamatan Tahunan Kabupaten Jepara.

${ }^{39}$ Wawancara dengan Eko Masnoor Frendi, Petingi Desa Semat pada 6 Desember 2019 di Desa Semat Kecamatan Tahunan Kabupaten Jepara. 
Masyarakat di desa kami, banyak yang menggeluti usaha bisnis online, salah satunya saya sendiri yang sudah 3 tahun belakangan ini memasarkan produk tenun, dengan berkembangnya alat komunikasi walaupun saya tinggal di desa tidak membuat semangat luntur, akhirnya saya bisa memperoleh hasil dari kerja keras yang sudah dilakukan. ${ }^{40}$

Sedangkan dampak negatif globalisasi di antaranya adalah memudarnya kearifan lokal, ketergantungan dengan alat teknologi, munculnya sikap individualistik, dan tingginya urbanisasi.

Budaya Barat yang bertentangan dengan budaya kita dengan mudah menggeser ke budaya asli kita. Mengakibatkan pudarnya kearifan lokal seperti tradisi menegur sapa, mengucapkan terima kasih, meminta tolong, dan lainlain. ${ }^{41}$

Juga pernyataan dari Siati, salah satu warga setempat berikut ini:

Karena kesibukan sehari-hari biasanya mengakibatkan masyarakat desa kurang bersosialisasi antar sesama masyarakat desa Semat apalagi sekarang banyak istri yang lebih memilih bekerja di pabrik untuk membantu suaminya dalam memenuhi kebutuhan hidup sehari-hari. ${ }^{42}$

Fenomena maraknya urbanisasi juga diamini oleh Petinggi Desa Semat:

Penduduk desa akhir-akhir ini Semat lebih memilih merantau ke luar kota bahkan ada yang sampai ke luar negeri, karena minimnya lapangan pekerjaan yang ada disini, menurut mereka dengan merantau hidup di kota lebih mudah untuk memenuhi kebutuhan hidup. ${ }^{43}$

Pengakuan dari Carik desa Semat jutru lebih ironis lagi. Globalisasi cenderung membawa dampak negatif ke warga.

Sekarang banyak ditemukan generasi muda yang hanya menghabiskan waktunya dengan hanya nongkrong, main game online setiap malam, jalan-jalan, bahkan menghambur-hamburkan uang untuk hal yang kurang bermanfaat. Padahal seharusnya di usia mereka sudah bisa dikatakan sebagai usia produktif atau memasuki usia yang bisa memilih melakukan sesuatu yang akan berguna untuk masa depannya. ${ }^{44}$

Para ahli menilai bahwa seseorang mengalami kecanduan atau ketergantungan pada internet disebabkan rasa cemas yang dimiliki individu, baginya menggunakan internet bisa digunakan untuk mengobati kesendirian dan sebagai pengganti hubungan tatap muka yang tidak diperolehnya dalam kehidupan sehari-hari karena takut untuk melakukan kontak langsung dengan orang laib dan lebih memilih komunikasi melalui online. $^{45}$

Dalam penelitian ini, dampak negatif era globalisasi di Desa Semat terfokus pada ketergantungan masyarakat dengan alat teknologi. Masyarakat semakin kecanduan dengan teknologi karena mereka selalu tertarik dengan teknologi yang semakin berkembang setiap waktu, dengan teknologi bisa membantu masyarakat untuk menjelajah dunia maya, bisa juga menambah pertemanan dan juga memudahkan dalam

40 Wawancara dengan Sinung, Warga Desa Semat, pada 2 januari 2020 di Desa Semat Kecamatan Tahunan Kabupaten Jepara.

41 Wawancara dengan H. Shofa, Carik Desa Semat pada 2 Desember 2019 di Desa Semat Kecamatan Tahunan Kabupaten Jepara.

42 Wawancara dengan Siati, Masyarakat Desa Semat pada 21 Oktober 2019 di Desa Semat Kecamatan Tahunan Kabupaten Jepara.

${ }^{43}$ Wawancara dengan Eko Masnoor Frendi, Petingi Desa Semat pada 6 Desember 2019 di Desa Semat Kecamatan Tahunan Kabupaten Jepara.

44 Wawancara dengan H. Shofa, Carik Desa Semat pada 2 Desember 2019 di Desa Semat Kecamatan Tahunan Kabupaten Jepara.

45 Silvia Fardila Soliha, "Tingkat Ketergantungan Pengguna Media Sosial Dan Kecemasan Sosial," Jurnal Interaksi 4, no. 1 (2015): 3, https://doi.org/10.14710/interaksi.4.1.1-10. 
melaksanakan kegiatan sehari-hari. Tapi, karena semakin seringnya masyarakat menggunakan gadget maka semakin sedikit interaksi sosial secara langsung dengan orang lain. Selain itu, juga banyak kejahatan di media sosial dengan memanfaatkan internet seperti pembobolan rekening nasabah bank, penipuan berkedok penjualan online, bagi anak-anak yang tidak dalam pengawasan orang tua bisa ketergantungan game online yang membuat mereka lupa waktu dan memboroskan dana. Anak-anak juga bisa mengakses layanan yang seharusnya tidak diperbolehkan.

Di antara upaya guru ngaji bersama pemerintah desa Semat dalam mempromosikan agenda SDGs yaitu:

1. Mengadakan kegiatan mengaji rutinan

Majlis taklim menjadi salah satu instrumen guru ngaji dalam upaya mengatasi dampak negatif era global. Seperti paparan Ustaz Sholihun di bawah ini:

Diadakannya kegiatan mengaji rutinan sangat bermanfaat bagi masyarakat. Contohnya rutinan ngaji buat para remaja, kegiatan mengaji Al-qur'an pada anak-anak setelah sholat maghrib, dan kegiatan dakwah bagi ibuk-ibuk pada hari-hari tertentu, dan dengan bapak-bapak. ${ }^{46}$

Kepala desa Semat juga menjelaskan:

Di desa Semat ada kegiatan mengaji rutinan yang dipimpin oleh guru ngaji dengan melibatkan masyarakat desa seperti dengan anak-anak setiap malam habis maghrib di rumah ustaz mengaji Al-qur'an dan kitab. Selain itu, dengan pemuda setiap 2 minggu satu kali di Masjid Baitul Izzah mengkaji Ilmu Figh dengan kitab Fathul Qorib, dan yang terakhir dengan ibu-ibu setiap hari Rabu dan Kamis dalam kegiatan Fatayatan, sedangkan dengan bapak-bapak setelah shalat subuh mengaji manaqib. ${ }^{47}$

Dengan adanya kegiatan mengajir rutinan dengan masyarakat bisa menghilangkan sifat individualis karena seringnya mereka berinteraksi. Juga bisa menambah keimanan dan pemahaman agama karena banyaknya ilmu yang didapat dari kegiatan pembelajaran.

2. Memberikan stimulus modal usaha yang bisa dikelola masyarakat

Caranya ialah dengan memanfaatkan keberadaan Badan Usaha Milik Desa (BUMDES) untuk membentuk dan mengembangkan usaha kecil dan menengah warga. UMKM berbasis desa dikelola oleh warga melalui organisasi karang taruna dan perkumpulan organisasi perempuan. Dengan adanya usaha tersebut bisa menyibukkan pemuda bisa meminimalisir pengangguran. Di antara usaha UMKM yang dikelola masyarakat Desa Semat diantaranya :

a) Dalam bidang fashion seperti usaha kain tenun yang digeluti sebagian pemuda Desa Semat.

b) Dalam bidang pendidikan seperti bimbingan belajar oleh pemuda desa yang bersedia dan memiliki pengetahuan lebih.

c) Dalam bidang kerajinan tangan seperti usaha gelang tenun yang dibuat sendiri oleh pemuda dengan memanfaatkan kain perca tenun yang sudah tidak terpakai.

d) Dalam bidang yang lain seperti pengembangan PKL (Pedagang Kaki Lima) khusus warga Desa Semat dengan memfasilitasi dibentuknya gazebo untuk berjualan di dekat pantai.

3. Kegiatan Kumpulan RT atau RW

Hampir sama dengan kegiatan mengaji di atas, adanya kegiatan rutinan RT

${ }^{46}$ Wawancara dengan Ustaz Sholihun, Ustaz Desa Semat pada 5 Desember 2019 di Desa Semat Kecamatan Tahunan Kabupaten Jepara.

${ }^{47}$ Wawancara dengan Eko Masnoor Frendi, Petingi Desa Semat pada 6 Desember 2019 di Desa Semat Kecamatan Tahunan Kabupaten Jepara. 
membuat masyarakat semakin dekat dengan tetangganya. Mereka merasa dihargai dan ditempatkan dalam posisi terhormat. Sesama warga desa bisa bebas untuk saling memberikan masukan positif dan menyampaikan gagasannya dalam upaya kemajuan Desa Semat.

Kegiatan kumpulan RT masyarakat Desa Semat dilakukan setiap dua minggu satu kali dengan cara idharohan ke rumah masing-masing warga antar RT. Kegiatan ini bisa dijadikan tempat buat masyarakat dalam menyampaikan aspirasinya, permasalahan yang terjadi, rencana ke depan dalam perkembangan desa dan lain-lain. Dengan mengutarakan apa yang ingin disampaikan dan memberikan masukan bagi orang lain yang sedang ada masalah membuat hubungan kekeluargaan menjadi semakin erat dan menambah pengetahuan bagi masyarakat yang jarang bersosialisasi dengan orang lain karena kesibukan sehari-hari. ${ }^{48}$

4. Kegiatan Sosial Berbasis Gotong Royong

Selain kegiatan mengaji rutinan, juga ada inisiasi melakukan agenda gotong royong di lingkungan desa. Seperti bersih-bersih pantai, mushalla, masjid, selokan, jembatan dan lain-lain. Dari kegiatan tersebut, solidaritas sosial kian erat. ${ }^{49}$

Setiap 2 minggu sekali pada hari Jum'at diadakan kegiatan bersih-bersih pantai Desa Semat. Pada hari tersebut, mayoritas masyarakat libur kerja. Ada juga kegiatan donor darah setiap 6 bulan sekali di balaidesa dan pemeriksaan bagi anak-anak juga lansia setiap satu bulan sekali. ${ }^{50}$

Kegiatan keagaaman lain yang dilakukan setiap satu tahun sekali yaitu sego gowok. Yaitu kegiatan tolak balak yang dilaksanakan di malam kedua bulan Muharram di Makam Mbah Sirah Sumosari (salah satu wali di Desa Semat).

Kegiatan sego gowok bermaksud memohon keselamatan, kerukunan masyarakat, dilimpahkan rizqi dan hajat yang lain kepada Allah SWT. Yang menjadi ciri khas dari kegiatan ini yakni setiap perwakilan keluarga membawa nasi liwet yang saat dimasak, dimasukkan telur ayam kampung (misal kepingin diparingi santen nggeh monggo tergantung masyarakatnya piyambak) kemudian nasi liwet dibawa langsung dengan tempat masaknya seperti magiccom atau panci. ${ }^{51}$

Dampak positif globalisasi disadari betul oleh tokoh pemuda yang ada di sana. masyarakat dituntut untuk terus berkembang agar tetap bisa dan mampu bersaing dalam berbagai aspek seperti ilmu pengetahuan, perekonomian, dan lain sebagainya. Oleh karena itu, pendidikan menjadi faktor yang sangat penting bagi generasi muda dalam mengasah skill yang dimiliki. ${ }^{\mathbf{5 2}}$

\section{KESIMPULAN}

Guru ngaji adalah sebutan yang disematkan pada seseorang yang ahli dalam ilmu agama dan bersedia mengajarkan apa yang dimilikinya kepada orang lain. Di Desa Semat terdiri lebih dari 2 ustaz yang mengajarkan mengaji Alquran dan kitab pada masyarakat desa tanpa membeda-bedakan satu sama lain. Atribut guru ngaji bukanlah pekerjaan yang mudah karena dalam mengamalkan ilmunya tidak mengharap materi

48 Wawancara dengan Supriyanto, Warga Desa Semat pada 23 Desember 2019 di Desa Semat Kecamatan Tahunan Kabupaten Jepara.

49 Wawancara dengan Ustaz Supa'at, Ustaz Desa Semat pada 5 Desember 2019 di Desa Semat Kecamatan Tahunan Kabupaten Jepara.

${ }^{50}$ Hasil observasi pada tanggal 23 Desember 2019 di Desa Semat.

${ }^{51}$ Wawancara dengan Eko Masnoor Frendi, Petingi Desa Semat pada 6 Desember 2019 di Desa Semat Kecamatan Tahunan Kabupaten Jepara.

${ }^{52}$ Wawancara dengan Khusnun Alif Rohman, Anggota Karang Taruna pada 5 Desember 2019 di Desa Semat Kecamatan Tahunan Kabupaten Jepara. 
apapun selain ridha dari Allah SWT. Tidak semua orang yang ahli agama bisa dikatakan guru ngaji. Ada beberapa kriteria yang mesti melekat, seperti cerdas, menguasai ilmu agama, berbagai ilmu pengetahuan kepada orang lain, tidak pernah mengharap gaji ataupun upah, mempunyai sifat-sifat terpuji, menjaga dirinya dan keluarganya dari sifatsifat tercela, bersedia memberikan masukan dan nasihat kepada masyarakat yang membutuhkan, dan lebih mementingkan kepentingan umum daripada kepentingan pribadi. Globalisasi memberikan dampak yang signifikan terhadap kehidupan warga Desa Semat. Pada industri meubel, contohnya, semuanya sudah menggunakan mesin, membajak sawah tak lagi memanfaatkan jasa hewan, sebagian masyarakat hampir setiap saat menggunakan gadget, dan aksses keluar desa semakin gampang. Sayangnya, dampak negatif era global juga sulit dihindari. Misalnya, pudarnya nilai-nilai kearifan lokal, berkurangnya sikap sosialisasi antar warga dengan kesibukan masing-masing, tingginya urbanisasi untuk memenuhi kehidupan sehari-hari, banyaknya pemuda yang kurang produktif karena malas bekerja. Peran guru ngaji dalam upaya mempromosikan target SDGs, utamanya dalam mengurangi kesenjangan ekonomi yang berujung pada kemiskinan dan pemerataan pendidikan di antaranya dengan mengadakan kegiatan mengaji rutinan, memperbanyak kegiatan sosial yang melibatkan masyarakat, memberikan usaha yang bisa dikelola masyarakat dan membekali ilmu agama sejak dini pada anak dan juga orang tua.

\section{DAFTAR PUSTAKA}

Aziz, Hamka Abdul. Karakter Guru Profesional Melahirkan Murid Unggul Menjawab Tantangan Masa Depan. Jakarta: Al Mawardi Prima, 2012.

Baggio, Roberto Abimanyu, and Rahma Rosaliana Saraswati. "Islam Menjawab Tantangan SDGS Di Indonesia : A Literatur Review." RISENOLOGI KPM UNJ 3, 2 (2018).

Fadhil, Al-Djamali. Menerobos Krisis Pendidikan Dunia Islam. Jakarta: PT Golden Terayon Press, 1993.

Gulo, W. Metodologi Penelitian. Jakarta: PT Grasindo, 2010.

H.M., Muhtarom. Reproduksi Ulama Di Era Globalisasi: Resistansi Tradisional Islam. Yogyakarta: Pustaka Pelajar, 2005.

Hamid, Ahmad Fauzi Abdul. "Globalization of Islamic Education in Southeast Asia," In Southeast Asian Muslims in the Era of Globalization. London: Palgrave Macmillan, 2015. https://doi.org/10.1007/s10531-009-9756-6.

Handi Khalifah, Mohamad, Mohammad Soleh Nurzaman, and Muhammad Cholil Nafis. "Optimization of BAZNAS Programs on Sustainable Development Goals (SDGs): Analytic Network Process Approach (ANP)." International Journal of Zakat 2, 2 (2017). https://doi.org/10.37706/ijaz.v2i2.26.

Indonesia, Presiden Republik. Peraturan Presiden Republik Indonesia Nomor 59 Tahun 2017 tentang Pelaksanaan Pencapaian Tujuan Pembangunan Berkelanjutan (2017).

Indra, Hasbi. Pendidikan Islam Tantangan Dan Peluang Di Era Globalisasi. Yogyakarta: Deepublish, 2016.

Ishartono, and Santoso Tri Raharjo. "Sustainable Development Goals (SDGs) Dan Pengentasan Kemiskinan." Share: Social Work Jurnal 6, 2 (2016). https://doi.org/10.5005/jp/books/13071_5.

Khoiriyah. Sosiologi Pendidikan Islam. Yogyakarta: Teras, 2012.

Kuntowijoyo. Pengantar Ilmu Sejarah. Yogyakarta: Yayasan Bintang Budaya, 1995.

Muhaimin. Pengembangan Kurikulum Pendidikan Agama Islam Di Sekolah, Madrasah, 
Dan Perguruan Tinggi. Jakarta: Radja Grafindo Persada, 2005.

Naim, Ngainum. Menjadi Guru Inspiratif. Yogyakarta: Pustaka Pelajar, 2019.

Nurhaidah, and M. Insya Musa. "Dampak Pengaruh Globalisasi Bagi Kehidupan Bangsa Indonesia.” Jurnal Pesona Dasar 3, 3 (2015): 1-14.

Panuluh, Sekar, and Meila Riskia Fitri. "Perkembangan Pelaksanaan Sustainable Development Goals (SDGs) Di Indonesia." Biefing Paper 02, (2016). http://www.sdg2030indonesia.org/an-component/media/uploadbook/Briefing_paper_No_1_SDGS_-2016-Meila_Sekar.pdf.

Rembangy, Musthafa. Pendidikan Transfoormatif. Yogyakarta: Teras, 2008.

Rifq, Muhammad. "Dampak Globalisasi Perdagangan Antara ASEAN-5 Dan China." Universitas Brawijaya, 2013.

Soliha, Silvia Fardila. "Tingkat Ketergantungan Pengguna Media Sosial Dan Kecemasan Sosial.” Jurnal Interaksi 4, 1 (2015). https://doi.org/10.14710/interaksi.4.1.1-10.

Soyomukti, Nurani. Pendidikan Berperspektif Globalisasi. Yogyakarta: Ar-Ruzz Media, 2008.

Sugiyono. Metode Penelitian Kuantitatif, Kualitatif, Dan R\&D. Bandung: Alfabeta, 2014).

Tafsir, Ahmad. Ilmu Pendidikan Dalam Perspektif Islam. Bandung: Remaja Rosdakarya, 2005.

“Tujuan SDG,” 2017. https://www.sdg2030indonesia.org/page/1-tujuan-sdg.

Ulum, Miftahul. "Pembinaan Kompetensi Ustadz Madrasah Diniyah Melalui Program Tarbiyatul Mu'allimin Di Madrasah Diniyah Takmiliyah Awwaliyah ArRosyidiyah Mambaul Ulum Pangarengan Sampang." MODELING: Jurnal Program Studi PGMI 6, 2 (2019). https://doi.org/10.36835/modeling.v6i2.448.

Wiley, John, and Sons. "The New Blackwell Companion to Social Theory," In Handbook of Research Methods in Health Social Sciences, edited by Bryan S. Turner. 2016. https://doi.org/10.1007/978-981-10-5251-4_57.

Zakki, Ahmad Izudin. "Peran Guru Ngaji Dalam Pembinaan Akhlaq Pemuda Di Dusun Pandan Desa Canggu Kecamatan Badas Kabupaten Kediri." UIN Maulana Malik Ibrahim Malang, 2019. http://etheses.uin-malang.ac.id/14411/1/14110086.pdf. 